\title{
ALLOCUTION DE CLOTURE DE/CLOSING SPEECH OF
}

\author{
M. Michael LANGER \\ Président de la l'Association Internationale de Géologie de l'Ingénieur
}

At the end of an International Symposium like this it has come to be a task but also a privilege of the President of the sponsoring Association to make a few closing remarks. I must confess that this task is not at all difficult to fulfull for this Symposium here.

I would like to give first of all our thaks to our French colleagues and to French institutions who have organized and operated this Symposium in such an outstanding way. I think that it has been a good idea to unite the know-how of specialized insitu testing in some countries and the demand for these techniques in orther countries. During the last four days all conceivable aspects of testing the earth's subsurface have been embraced.

Field Measurements carried out prior to and during the construction of rock structures are widely recognized as one of the most important sources of information for safe and economic design.

The purpose that may be pursued when organizing a large Symposium as this one and which the President of the Symposium Mr. Parez has claimed when opening the Symposium were fully reached. Indeed :

1. the specialists of engineering geology geophysies and geotechnics from all over the world has an opportunity to present the results of their activity, which is well illustrated by the large number of papers submitted;

2. the general reports and panel reports presented an over all view of the present stage of in situ testing

3. participants had many opportunities during the session and outside the to exchange ideas; and

4. the Symposium has allowed the organization of very valuable exhibitions and visits. So, we are very much indebted to our French colleagues and friends.

I think the success of this Symposium is also due to the fact that engineering geology and geotechnics is of central importance for the public humanity, as safe and economic construction of dams, reservoirs, tunnels, caverns and so on mainly depends on accurate investigations. They really can help to prevent failures or at least contribute to minimize the damages of natural catastrophic events.

Computer analyses can be of great value for this purpose, but the reliability of the answers they produce can only be as good as the data fed into them. The input data are largely of engineering geological type or at least are data that need some engineering geological interpretation.

Engineering geologists recognise the need for realisticially based techniques and procedures with which to quantify their data, and will continue to optimize the methods to acquire these parametus. More extensive systematic and objective observation and instrumentation on civil engineering projects, employed before, during and after construction, would do much to enhance our understanding and effectiveness in these fields of geotechnics.

As conclusion I wish to present to the Organizing Committee and specially its Secretary Dr. André Peter our most sincere and enthusiastic thanks for the efforts spent to neach a complete success of the Symposium and for the extremely cordial atmosphere they were able to create among all the participants. I personally was pleased to have shared the company of so many well-known experts. To those who'll go on excursion I wish some more good days, to all the others a good way back home. 